\title{
Tadeusz Jędrysiak, Armin Mikos von Rohrscheidt, Militarna turystyka kulturowa, Polskie Wydawnictwo Ekonomiczne, Warszawa 2011, ss. 294
}

(c) $\underset{\mathrm{BY}}{\ominus}$ DD DOI: http://dx.doi.org/10.12775/KLIO.2013.027

\section{$\mathrm{M}$} oda na turystykę związaną z odwiedzaniem miejsc o charakterze czysto wojskowym lub - w różnych aspektach - militarnym w Polsce nie była znacznie rozwinięta do początku lat dziewięćdziesiątych XX wieku. Dopiero ostatnie dwudziestolecie przyniosło wiele zmian na w tym zakresie. Zadania przedstawienia obiektów, miejsc, instytucji oraz wszelkich innych form kultywujących dziedzictwo narodowe (nie tylko polskie) znajdujących się w obecnych granicach kraju podjęli się Tadeusz Jędrysiak i Armin Mikos von Rohrscheidt - autorzy pracy Militarna turystyka kulturowa, wydanej nakładem Polskiego Wydawnictwa Ekonomicznego ${ }^{1}$.

Pierwszy z autorów książki, Tadeusz Jędrysiak, to doktor nauk technicznych Politechniki Warszawskiej. Od wielu lat zaangażowany jest w rozwój turystyki, pracuje również w tej branży. Drugi twórca publikacji - Armin Mikos von Rohrscheidt posiada szerokie wykształcenie, m.in. doktorat $\mathrm{w}$ dziedzinie nauk o kulturze w zakresie turystyki kulturowej Uniwersytetu im. Adama Mickiewicza. Wśród wielu inicjatyw, w których bierze udział, warto wymienić, to, że jest pomysłodawcą i redaktorem naczelnym miesięcznika naukowego „Turystyka Kulturowa”. Obaj autorzy książki mają w swoim dorobku m.in. kilka prac $^{2}$ i wiele artykułów o tematyce związanej z turystyką kulturową ${ }^{3}$.

${ }^{1} \mathrm{~W}$ tej recenzji autor skupił się głównie na przedstawieniu obecnych w treści Militarnej turystyki kulturowej licznych niedociągnięć dotyczących poprawności historycznej, gdyż ocena tej strony pracy została praktycznie całkowicie pominięta w recenzji książki autorstwa Ewy Malchrowicz, opublikowanej w miesięczniku „Turystyka Kulturowa” 2011, nr 10, s. 35-40.

2 T. Jędrysiak, Turystyka kulturowa, Warszawa 2008; idem, Wiejska turystyka kulturowa, Warszawa 2010; A. M. v. Rohrscheidt, Turystyka kulturowa. Fenomen, potencjat, perspektywy, Gniezno 2008.

3 Zob. m.in.: A. M. v. Rohrscheidt, Polska: największe muzeum fortyfikacji na wolnym powietrzu w aspekcie rozwoju turystyki kulturowej, „Turystyka Kulturowa” 2009, 
Publikację podzielono na pięć rozdziałów. W pierwszym przedstawiono ogólne zagadnienia wprowadzające, dotyczące militarnej turystyki kulturowej. Chociaż zasadniczo praca prezentuje polską problematykę oraz realia, w rozdziale tym ukazano także główne aspekty europejskie i północnoamerykańskie tytułowych kwestii. W kolejnej części pod wzniosłym tytułem Militarne aspekty i elementy dziedzictwa kulturowego w Polsce omówiono w wielkim skrócie polską historię wojskową, od okresów najdawniejszych po czasy współczesne. Zarówno ten, jak i następny rozdział, w którym przedstawiono pierwotne atrakcje militarnej turystyki kulturowej w Polsce (takie, jak: pola bitew, cmentarze i - przede wszystkim - fortyfikacje), to pod względem merytorycznym zdecydowanie najsłabsze części pracy, co zostanie uzasadnione w dalszej części recenzji. Ostatnie dwa rozdziały prezentują formy organizacji omawianej turystyki w Polsce (rozdział IV) oraz jej rozwój w polskich warunkach (rozdział V).

Kompozycja pracy - mieszana, problemowo-chronologiczna - nie należy do idealnych w tym wypadku, gdyż do wielu aspektów powraca się na łamach książki kilkukrotnie. Czasem nawet autorzy po prostu przeredagowali krótkie opisy, np. konkretnych obiektów militarnych, dodając inne, charakterystyczne dla kolejnego rozdziału informacje. Wiele nieścisłości i pomyłek w tekście spowodowanych jest pobieżnym opisaniem wielu zagadnień, co można usprawiedliwić tematem publikacji. Nie szczędzono jednak miejsca na obszerne przypisy, w których autorzy rozwodzą się nad kwestiami nieistotnymi z punktu widzenia celu niniejszej publikacji, m.in. podają funkcjonujące $\mathrm{w}$ literaturze różne daty określające początek III Rzeczypospolitej (s. 59), zamieszczają definicję Układu Warszawskiego (s. 58) oraz NATO (s. 61), czy też przedstawiają rozważania nad terminem „bitwa” (s. 128). Jest to pewną przesadą w stosunku do tematu i zakresu pracy.

Pomimo pewnego rozmachu (mając na uwadze charakter publikacji) w przedstawianiu dziejów polskich sił zbrojnych we wczesnych okresach dziejów (średniowiecze, czasy nowożytne), zdumiewa brak jakichkolwiek ogólnych informacji o polskim wysiłku zbrojnym w okresie 1831-1914

nr 2, s. 20-48; idem, Polskie szlaki turystyczno-kulturowe - kryteria i zasady waloryzacji potencjatu, „Turystyka Kulturowa” 2009, nr 4, s. 4-28. 
(s. 47-61). Lakonicznie potraktowano również Wojsko Polskie w okresie II Rzeczypospolitej, poświęcając temu zagadnieniu zaledwie jeden akapit (s. 54-55).

W publikacji odnaleźć można wiele rozmaitych błędów. Czytelnicy powinni zwrócić uwagę przynajmniej na niektóre z nich. Na początku warto wspomnieć o występujących w treści dość licznych, zarówno poważniejszych, jak i drobnych błędach dotyczących datacji wydarzeń historycznych. W książce podano lata 1409-1410 (zamiast 1409-1411) jako okres trwania tzw. „wielkiej wojny z zakonem krzyżackim” (s. 78) ${ }^{4}$. Bardzo podobna pomyłka to określenie daty obrony grodu w Niemczy na rok 1027 (prawidłowo - 1017 r.). W książce znalazła się także niepoprawna data bitwy warszawskiej, która według autorów odbyła się w dniach 16-17 VIII 1920 roku (s. 135). Na s. 158 podano również błędne daty trwania wojny siedmioletniej - 1753-1760. Do intrygujących stwierdzeń należy fragment ze s. 132, nie wymagający komentarza: „bitwa pod Gniewem, 1626 r. [...] była drugą w historii porażką husarii (pierwsza - bitwa pod Tczewem, 1627 r., porażka jazdy polskiej [...])”. W pracy zamieszczono mylną część tytułu i datę wydania znanego dzieła Adama Freytaga traktującego o architekturze obronnej (s. 79) - prawidłowo tytuł (skrócony) brzmi: Architectura Militaris (a nie Militaria), a zamiast 1635 r. powinien być rok $1631^{5}$.

Kolejnym przykładem braku ścisłości są różne błędne określenia i datacje wojny polsko-sowieckiej, trwającej w latach 1919-1921, którą raz wymieniono jako „wojnę polsko-bolszewicką (1919-1921)” (s. 83), w innym miejscu jako „wojnę polsko-radziecką (1919-1920)” (s. 84), w jeszcze innym fragmencie pracy określoną jako „wojna polsko-sowiecka (19191920)" (s. 135).

Znaczna część pracy poświęcona jest różnym aspektom związanym z architekturą obronną na obszarze Polski, zarówno w jej obecnych, jak i dawnych granicach. Większość opisów jest prawidłowa, jednak w podroz-

${ }^{4}$ Por.: S. M. Kuczyński, Wielka wojna z zakonem krzyżackim w latach 1409-1411, Warszawa 1987; S. Jóźwiak, K. Kwiatkowski, S. Szybkowski, Wojna Polski i Litwy z zakonem krzyżackim w latach 1409-1411, Malbork 2010.

5 T. M. Nowak, Adam Freytag i jego Architectura Militaris Nova et Aucta..., [w:] Twierdza Toruń - stan badań i problematyka konserwatorska, Fortyfikacja, t. 5, red. L. Narębski, Warszawa-Kraków 1998, s. 10. 
działach dotyczących historii umocnień, ich aktualnego stanu i możliwości wykorzystania pod względem turystycznym, odnaleźć można kilka błędów, opisanych poniżej.

W II Rzeczypospolitej nie istniał „Obszar Warowny Hel”, jak podano na s. 121. Półwysep helski miał status Rejonu Umocnionego ${ }^{6}$. Twierdza Grudziądz, mimo że została określona ,jedną z największych twierdz fortowych w Polsce” (s. 157), nie została wymieniona wśród wielu „miejscowości z najciekawszymi obiektami militarnymi zbudowanymi od XVII wieku do początku I wojny światowej” (s. 155), choć znalazły się tam z pewnością mniej interesujące zespoły fortyfikacji. Ponadto umiejscowiono budowę twierdzy fortowej w XVIII wieku (s. 157), mimo że w tym okresie (do początku XIX wieku) powstała wyłącznie cytadela, centrum przyszłego, wspomnianego wyżej typu twierdzy ${ }^{7}$. Odnosząc się do opisu oferty turystycznej - „turyści mogą zwiedzać niemal wszystkie forty” (s. 157) - należy wskazać, że z jedenastu istniejących pierwotnie fortów obejrzeć można osiem, z czego jeden (Fort Strzemięcin) jest w stanie częściowej ruiny (silne zniszczenie substancji schronu głównego, dobrze zachowana struktura ziemna). Pozostałe nie istnieją (Fort Gać i Fort Tuszewo) lub jako własność prywatna pozostają zamknięte ${ }^{8}$ Natomiast samo zwiedzanie może mieć wyłącznie charakter indywidualny, gdyż umocnienia nie są przystosowane do pełnienia typowej, ogólnej funkcji turystycznej ${ }^{9}$.

Nieprecyzyjna jest informacja dotycząca Twierdzy Kłodzko, która nie była - jak napisał autor - „bezskutecznie oblegana w 1807 roku przez woj-

${ }^{6}$ Dz. U. RP, 1936, nr 71, poz. 512; Pótwysep helski. Historia orężem pisana, red. A. Drzewiecki, M. Kardas, Toruń 2009, s. 202-209.

7 J. Stankiewicz, Twierdza grudziądzka, „Rocznik Grudziądzki” 1970, t. 5-6, passim; K. Biskup, Twierdza Grudziądz na przetomie XIX i XX wieku, „Rocznik Grudziądzki” 1992, t. 10, s. 59-65.

${ }^{8}$ Fort Wielka Księża Góra, który udostępniany jest do zwiedzania jedynie incydentalnie. Warto zaznaczyć, że jest to z pewnością najciekawszy z grudziądzkich fortów.

9 Pod tym określeniem autor rozumie taką formę udostępniania obiektów, jaka ma miejsce np. w fortach dawnej Twierdzy Świnoujście lub w Forcie IV w Toruniu. Dana fortyfikacja jest wówczas przystosowana do obsłużenia ruchu turystycznego i obiekt bezpiecznie mogą zwiedzać nie tylko samodzielni turyści kwalifikowani, ale także całe rodziny z dziećmi. Należy podkreślić, że wspomniana kwestia nie dotyczy wyłącznie twierdzy grudziądzkiej. 
ska napoleońskie" (s. 158), ale skapitulowała, a następnie pozostała w pruskich rękach ze względu na zawarcie pokoju w Tylży ${ }^{10}$. Z kolei w przedstawieniu oferty turystycznej dawnej Twierdzy Toruń można przeczytać, że: „niektóre z fortów są w pełni przygotowane do obsługi ruchu turystycznego" (s. 168). Do tego celu przystosowane są wyłącznie dwa forty ${ }^{11}$, a całkowicie tylko jeden, wymieniony w publikacji Fort IV. W szerokim omówieniu propozycji dla turystów pragnących zwiedzić twierdzę zamojską, autor pominął fakt istnienia od kilku lat trasy turystycznej w Bastionie VII oraz Nadszańcu (s. 172). W zestawieniu pozycji obronnych z okresu II wojny światowej (s. 173) dwukrotnie (jako różne) wymieniono umocnienia: Pozycja Pomorska i Wał Pomorski, mimo że określenia te dotyczą jednej, tej samej linii fortyfikacji, w języku niemieckim zwanej Pommernstellung.

$\mathrm{Z}$ kolei w rozdziale $\mathrm{V}$ znalazła się informacja dotycząca utworzenia szlaków obiektów militarnych, w tym Regionalnego Kujawsko-Pomorskiego Szlaku Umocnień. Wśród budowli (twierdz i pozycji), które miałby on objąć, autor wymienił „Ufortyfikowane Przedmoście Chełmno” (s. 279), mimo że Chełmno posiadało w swojej historii status „twierdzy” ${ }^{2}$. Poza sprawą formalną, dla zwrócenia uwagi czytelnika i podniesienia atrakcyjności turystycznej miejsca, korzystniejsze byłoby użycie właśnie tego terminu.

W publikacji zamieszczono też błędne informacje dotyczące częściowo ufortyfikowanych mostów w Tczewie. Pierwszy, który wzniesiono, był jednotorowym mostem kolejowym, a nie drogowym (s. 168). Natomiast

${ }^{10}$ J. Dudziński, Dezercja w armii pruskiej na Śląku w czasie wojny 1806-1807, [w:] Twierdza srebrnogórska II. Wojna 1806-1807-miasteczko, red. T. Przerwa i G. Podruczny, Wrocław 2008, s. 95.

${ }^{11}$ Fort IV. Warownia Stanisława Żółkiewskiego i Fort VI. Warownia Jaremy Wiśniowieckiego (wg numeracji i nazewnictwa polskiego z okresu międzywojennego), M. Giętkowski, Z. Karpus, W. Rezmer, Twierdza Toruń. Stan w latach dwudziestych XX wieku: dokumenty, Toruń 2004, s. 176, 185.

${ }^{12}$ K. Biskup, Fortyfikacje dolnej Wisty w przededniu I wojny światowej, [w:] Konserwatorska Teka Zamojska, cz. 2, red. L. Krzyżanowski, Warszawa-Zamość 1988, s. 33. Szerzej zob.: M. Malinowski, Mosty na Wiśle w Tczewie, „Świat Kolei” 2001, nr 5, s. $18-23$.. 
w latach 1888-1891 powstał drugi most kolejowy, tym razem dwutorowy. Do użytku drogowego od 1891 roku przeznaczono pierwszą przeprawę ${ }^{13}$.

Czytelnik z pewnością zauważy również fakt, że poszczególne obiekty wymieniane w pracy, pomimo podobnego znaczenia i obecnych walorów opisywane są w nieujednolicony sposób. Irytujące mogą okazać się pojawiające się w kilku miejscach w publikacji powtórzenia takich samych informacji, zwłaszcza tych posiadających charakter szczegółowy (np. na s. 49 i s. 50 ; s. 52 i s. 65 ; s. 182 i s. 212). Wśród innych uchybień występujących w książce, warte odnotowania jest to, że większość podawanych danych liczbowych nie została poparta odwołaniem do konkretnej informacji źródłowej.

$\mathrm{Z}$ pozostałych błędów zwracają uwagę także następujące kwestie. Opisując dzieje Orderu Virtuti Militari, wspomniano Katarzynę I jako panującą w Imperium Rosyjskim w 1794 r. (s. 67); w rzeczywistości caryca już wówczas nie żyła od ponad pół wieku, a tekst dotyczy Katarzyny II (władającej w latach 1762-1796) ${ }^{14}$. Podając klasy Orderu Krzyża Wojskowego popełniono pomyłkę, określając jako II klasę - Krzyż Kawalerski, a III klasę - Krzyż Komandorski (s. 70), zamiast odwrotnie ${ }^{15}$.

Do drobnych błędów, nie ujmujących wartości tego rodzaju publikacji, należy zaliczyć używanie niepoprawnej terminologii, np. „bunkier” (co ciekawe, wyraz ten występuje w książce zarówno jako synonim terminu „schron”, jak i jako nazwa odrębnego rodzaju fortyfikacji), a także: „transzeja”, „kampania wrześniowa”, „wojna obronna Polski 1939”. Warto jednak podkreślić, że większość pojęć zostało w pracy zastosowanych w sposób poprawny.

Niebłahą kwestią, którą szczególnie należy uwypuklić, jest skopiowanie fragmentu tekstu z popularnej Wikipedii, z wprowadzeniem jedynie kosmetycznych poprawek. Tekst, o którym mowa to całościowe omówienie Pozycji (Linii) Odry (s. 179). W Wikipedii wspomniany wyjątek jest czę-

${ }^{13}$ K. Biskup, Fortyfikacje dolnej Wisty $w$ przededniu I wojny światowej, [w:] Konserwatorska Teka Zamojska, cz. 2, red. L. Krzyżanowski, Warszawa - Zamość 1988, s. 33; A. Massel, M. Malinowski, Mosty na Wiśle w Tczewie, „Świat Kolei” 2001, nr 5.

14 W. Serczyk, Katarzyna II, Warszawa 2004, passim.

15 Dz. U. RP, 2006, nr 194, poz. 1432, Ustawa z dnia 18 października 2006 r. o zmianie ustawy z dnia 16 października 1992 r. o orderach $i$ odznaczeniach. 
ścią hasła Linia Środkowej Odry ${ }^{16}$. W pracy nie zamieszczono nawet stosownego przypisu, co i tak nie miałoby dużego znaczenia w takim przypadku; natomiast hasło w Wikipedii posiada dość obszerną literaturę przedmiotu. Można mieć tylko nadzieję, że w książce jest to odosobniony „wypadek”, który jednak wzbudza pewne obawy.

Oprócz wszystkich omówionych powyżej, w pracy znajdują się jeszcze inne drobne błędy rzeczowe, niekonsekwencje oraz pomyłki związane z niewłaściwą datacją wydarzeń. Niezbyt rozsądne było zamieszczenie w niej skrótowego opisu tak wielu aspektów związanych z polską historią wojskową. Nie uniknięto przez to wielu nieścisłości, a przede wszystkim bezpośrednich błędów. Można również wyrazić postulat, aby w publikacjach tego typu - niewątpliwie potrzebnych na rynku wydawniczym - do przedstawienia zagadnień historycznych przywiązywano więcej uwagi lub ograniczano się do prezentacji najbardziej niezbędnych, ale precyzyjnych informacji.

Podstawową zaletą książki jest próba całościowego opracowania tematu. Części publikacji opisujące ściśle tytułowe zagadnienia (głównie rozdziały IV i V) poruszają wiele istotnych kwestii związanych z różnymi aspektami militarnej turystyki w Polsce i jej uwarunkowaniami do realizacji, na tle wybranych przykładów organizacji tego typu turystyki w Europie Zachodniej oraz na świecie, głównie w Stanach Zjednoczonych. W trafny sposób zasygnalizowano także istotny problem wykupu i przechodzenia w posiadanie prywatnych właścicieli wielu dawnych obiektów obronnych (s. 187), zwłaszcza dużych fortyfikacji, takich jak różnego rodzaju forty budowane w drugiej połowie XIX i na początku XX wieku. Umocnienia takie często bezpowrotnie tracone są na rzecz ich wykorzystania w dowolnych celach, często zupełnie sprzecznych z turystyką czy ochroną zabytków.

Język jakim została napisana praca jest poprawny $\mathrm{i}$ barwny. Jednocześnie autorzy dołożyli starań, aby był on zrozumiały dla różnych grup odbiorców. Błędy w druku oraz drobne potknięcia językowe są nieliczne. Zagadnienia prezentowane są w pracy dość jasno i atrakcyjnie, m.in. wiele informacji podanych jest $\mathrm{w}$ formie tabel. Cennym uzupetnieniem

${ }^{16}$ Linia Środkowej Odry, http://pl.wikipedia.org/wiki/Linia_Środkowej_Odry, [dostęp z dnia 12.04.2013 r.]. 
są mapy oraz rysunki i liczne fotografie, ukazujące militarne dziedzictwo kulturowe w Polsce. Książka została wydana schludnie, a zamieszczony materiał ilustracyjny prezentuje się bez zarzutów.

Publikację Militarna turystyka kulturowa należy ocenić dwojako. Na pierwszy plan wysuwa się ciemniejsza strona - treść zawiera wiele różnych błędów - najczęściej rzeczowych, zwłaszcza dotyczących datacji, nieścisłości $\mathrm{w}$ prezentowaniu oferty turystycznej, rzadziej związanych $\mathrm{z}$ terminologią. $\mathrm{Na}$ pracę cień rzuca też wskazany przypadek skopiowania gotowego tekstu. $\mathrm{Z}$ drugiej strony książka jest pozycją pożądaną na rynku ze względu na poruszaną problematykę oraz fakt całościowego spojrzenia na temat. Odnaleźć w niej można wiele cennych spostrzeżeń dotyczących uwarunkowań turystyki w naszym kraju. Z pewnością zasadnicze cele jej napisania, tj. powiększenie zakresu wiedzy o militarnym potencjale turystycznym Polski, a także inicjowanie dyskusji dotyczącej perspektyw rozwoju w tej dziedzinie, zostały zrealizowane. Publikację można polecić czytelnikom zainteresowanym poznaniem historycznego, militarnego dziedzictwa w Polsce. Należy jednak przestrzec przed traktowaniem zawartych w pracy informacji dotyczących historii wojskowej jako pierwszorzędnej wykładni wiedzy. Odbiorcy publikacji z pewnością dobrze przyjęliby drugie, poprawione wydanie. 